\title{
Intraoperative 3D transoesophageal valvular evaluation
}

\author{
T Anguseva ${ }^{*}$, I Milev, E Idoski, Z Mitrev \\ From 23rd World Congress of the World Society of Cardio-Thoracic Surgeons \\ Split, Croatia. 12-15 September 2013
}

\section{Background}

The aims of this study were to evaluate the feasibility of real-time 3-dimensional (3D) transesophageal echocardiography in the intraoperative assessment of valvular pathology and to compare this novel technique with 2-dimensional (2D) transesophageal echocardiography.

\section{Methods}

450 consecutive patients undergoing valvular were studied prospectively. Intraoperative $2 \mathrm{D}$ and $3 \mathrm{D}$ transesophageal echocardiographic (TEE) examinations were performed using a recently introduced TEE probe that provides realtime 3D imaging. Expert echocardiographers blinded to 2D TEE findings assessed the etiology of MR on 3D transesophageal echocardiography.

Similarly, experts blinded to 3D TEE findings assessed 2D TEE findings. Both were compared with the anatomic findings reported by the surgeon.

\section{Results}

At the time of surgical inspection, ischemic MR was identified in $12 \%$ of patients, complex bileaflet myxomatous disease in $31 \%$, and specific scallop disease in $25 \%$, aortic stenosis in $20 \%$ and insufficiency in $12 \%$ of patients. Three-dimensional TEE image acquisition was performed in a short period of time (60-18 seconds) and was feasible in all patients, with optimal (36\%)or good (33\%) imaging quality in the majority of cases. Three-dimensional TEE imaging was superior to $2 \mathrm{D}$ TEE imaging in the diagnosis of P1, A2, A3, and bileaflet disease (P 0 .05), as well as in aortic stenosis and insufficiency evaluation (leaflet morphology).

\section{Conclusions}

Real-time 3D transesophageal echocardiography is a feasible method for identifying specific valvular pathology

\footnotetext{
* Correspondence: tanja@cardiosurgery.com.mk

Special Hospital for Surgery Fillip II, Skopje, Macedonia
}

in the setting of complex disease and can be expeditiously used in the intraoperative evaluation of patients undergoing valvular repair surgery.

Published: 11 September 2013

doi:10.1186/1749-8090-8-S1-079

Cite this article as: Anguseva et al:: Intraoperative 3D transoesophageal valvular evaluation. Journal of Cardiothoracic Surgery 2013 8(Suppl 1):O79.
Submit your next manuscript to BioMed Central and take full advantage of:

- Convenient online submission

- Thorough peer review

- No space constraints or color figure charges

- Immediate publication on acceptance

- Inclusion in PubMed, CAS, Scopus and Google Scholar

- Research which is freely available for redistribution
() Bïomed Central

\section{CiolMed Central}

(c) 2013 Anguseva et al; licensee BioMed Central Ltd. This is an Open Access article distributed under the terms of the Creative Commons Attribution License (http://creativecommons.org/licenses/by/2.0), which permits unrestricted use, distribution, and reproduction in any medium, provided the original work is properly cited. 